\title{
INNOVATIVE MATERIALS AND TECHNOLOGIES FOR SUSTAINABLE PRODUCTION IN LEATHER AND FOOTWEAR SECTOR
}

\author{
MATERIALE ŞI TEHNOLOGII INOVATOARE PENTRU O PRODUCTIE DURABILĂ ÎN SECTORUL PIELĂRIE- \\ ÎNCĂLTĂMINTE
}

\author{
Viorica DESELNICU ${ }^{1 *}$, Marian CRUDU ${ }^{1}$, Gabriel ZĂINESCU ${ }^{1}$, Mădălina Georgiana ALBU ${ }^{1}$, Dana Corina DESELNICU ${ }^{1,2}$, Sergiu \\ Adrian GUTĂ ${ }^{1}$, loannis IOANNIDIS ${ }^{1,3}$, Dana GURĂU ${ }^{1}$, Laurenţia ALEXANDRESCU ${ }^{1}$, Rodica Roxana CONSTANTINESCU ${ }^{1}$, Corina \\ CHIRILÄ ${ }^{1}$, Gabriela MACOVESCU ${ }^{1}$, Gheorghe BOSTACA ${ }^{1}$
}

${ }^{1}$ INCDTP - Division Leather and Footwear Research Institute, Bucharest, Romania, email: icpi@icpi.ro

${ }^{2}$ Politehnica University of Bucharest, Romania, email: d_deselnicu@yahoo.com

${ }^{3}$ ME-MED Consultants for Leather Industry, Athens, Greece, email: ioannidisioa@gmail.com

\section{INNOVATIVE MATERIALS AND TECHNOLOGIES FOR SUSTAINABLE PRODUCTION IN LEATHER AND FOOTWEAR SECTOR}

ABSTRACT. Leather industry has to cope nowadays with major environmental problems because of the polluting processes. Therefore, increasing the environmental efficiency in the leather sector is the major aim of leather, auxiliary materials and equipment manufacturers. The development of new tanning agents and new technologies is required to cope with the increasingly higher environmental pressure on the current tanning materials and processes such as tanning with chromium salts. This paper presents the main results obtained in the framework of INNOVA LEATHER project. The original contribution of this project in solving the above problems has involved the use of solid titanium wastes (cuttings) resulting from the process of obtaining highly pure titanium (ingots) in the preparation of new tanning compounds intended to increase the environmental efficiency of the leather sector. Also, within the above line, the aim is to obtain wetwhite leather by an organic tanning process in order to reduce chromium in tannery effluent. Another result obtained in the project is valorization of wet white leather waste as raw material for obtaining new biodegradable auxiliaries with application in agriculture, cosmetics and chemicals.

KEY WORDS: tanning agents, wet white, FOC leather, waste valorization, cosmetics, soil remediation, sustainable development

\section{MATERIALE ŞI TEHNOLOGII INOVATOARE PENTRU O PRODUCTIE DURABILĂ ÎN SECTORUL PIELĂRIE-ÎNCĂLTĂMINTE}

REZUMAT. Industria de pielărie trebuie să facă faţă în prezent unor probleme de mediu majore datorate proceselor poluante. Prin urmare, creşterea eficienţei de mediu în sectorul de pielărie este obiectivul major al producătorilor de piele, materiale auxiliare şi echipamente. Este necesară dezvoltarea unor noi agenţi de tăbăcire şi noi tehnologii pentru a face faţă presiunii de mediu din ce în ce mai mare asupra materialelor şi proceselor de tăbăcire actuale, cum ar fi tăbăcirea cu săruri de crom. Această lucrare prezintă principalele rezultate obţinute în cadrul proiectului INNOVA-LEATHER. Contribuţia originală a acestui proiect la rezolvarea problemelor menţionate mai sus a implicat utilizarea deşeurilor solide de titan (şpan) rezultate din procesul de obşinere a titanului foarte pur (lingouri) în prepararea unor noi compuşi tananţi cu scopul de a creşte eficienţa ecologică a sectorului de pielărie. De asemenea, în acelaşi context, scopul a fost de a obţine piele wet-white printr-un proces de tăbăcire organică, pentru a reduce cantitatea de crom din efluenţii din tăbăcărie. Alte rezultate obţinute în cadrul proiectului sunt valorificarea deşeurilor de piele wet-white ca materie primă pentru obţinerea unor noi auxiliari biodegradabili cu aplicaţii în agricultură, produse cosmetice şi substanţe chimice.

CUVINTE CHEIE: agenţi tananţi, wet white, piele fără crom, valorificarea deşeurilor, cosmetice, remedierea solului, dezvoltare durabilă

\section{DES MATÉRIAUX ET DES TECHNOLOGIES INNOVANTES POUR LA PRODUCTION DURABLE DANS LE SECTEUR DU CUIR ET DES CHAUSSURES}

RÉSUMÉ. L'industrie du cuir doit maintenant faire face à des problèmes environnementaux majeurs causés par des procédés polluants. Par conséquent, l'augmentation de l'efficacité de l'environnement dans le secteur du cuir est le principal objectif des fabricants de cuir, des matériaux auxiliaires et des équipements. Il est nécessaire de développer de nouveaux agents de tannage et de nouvelles technologies pour faire face aux pressions environnementales de plus en plus élevées sur les matériaux et les processus de tannage actuels tels que le tannage au sels de chrome. Cet article présente les principaux résultats du projet INNOVALEATHER. La contribution originale de ce projet pour résoudre les problèmes mentionnés ci-dessus implique l'utilisation de déchets solides de titane (feraille) issus de la procédure d'obtention du titane très pur (lingots) dans la préparation de nouveaux composés de tannage afin d'augmenter l'efficacité environnementale du secteur du cuir. Toujours dans ce contexte, l'objectif était d'obtenir du cuir wet-white par un processus de tannage organique pour réduire la quantité de chrome dans les effluents de tannerie. Autres résultats obtenus dans le projet sont la valorisation des déchets de cuir wet-white comme matière première pour la production de nouveaux auxiliaires biodégradables avec applications dans l'agriculture, des produits cosmétiques et des produits chimiques.

MOTS-CLÉS: agents de tannage, cuir wet white, cuir sans chrome, valorisation des déchets, produits cosmétiques, assainissement des sols, développement durable

\footnotetext{
* Correspondence to: Viorica DESELNICU, INCDTP - Division Leather and Footwear Research Institute, 93 Ion Minulescu, sector 3, 031215 Bucharest, Romania, email: icpi@icpi.ro
} 


\section{INTRODUCTION}

Chrome tanning is the most common type of tanning in the world. Chrome tanned leathers are characterised by top handling quality, high hydrothermal stability and excellent user properties. Chrome waste from leather processing poses a significant disposal problem. It occurs in three forms: liquid waste, solid tanned waste and sludge. In most countries, regulations governing chrome discharge from tanneries are stringent. Today, all tanneries must thoroughly check their waste streams. Chrome discharge into those streams is one of the components that has to be strictly controlled.

The environmental impact of chrome waste from tanneries has been a subject of extensive scientific and technical dispute. Statutory limits have since been set for chrome discharge and disposal, and relevant guidelines have been drawn up throughout the world.

Given the close correlation between chrome tanning and the environmental impact of leather processing, auditing the efficiency of processing operations takes on prime importance.

Conventional chroming process generally involves pickling, chroming and basifying, and there are several defects in the process $[1,2]$ : i) $8-10 \%$ salt and $1.0-1.2 \%$ sulfuric acid are used in pickling, which results in higher contents of chlorides, sulfates and chemical oxygen demand (COD) in the effluent; ii) the uptake of chromium in conventional chroming is lower (70-80\%), a considerable amount of chromium left in the effluent may result in environmental problems [3]; iii) a great deal of chrome containing solid wastes such as splittings and shavings are produced, which are certainly difficult to be degraded and harmful for the environment if discharged directly.

Much criticism has been directed towards the use of chromium salts in leather tanning, but it has to be borne in mind that chromium can occur in different oxidation states and its compounds behave differently. Most chromium(VI) compounds are highly toxic and classified as MAK III A 2 carcinogens, but chromium(III) is an important trace element in man and animals. Chrome is mentioned in list 2 of the Annex to Council Directive 76/464/EEC of 4 May 1976 on pollution caused by certain dangerous substances discharged into the aquatic environment of the Community.

\section{INTRODUCERE}

Tăbăcirea în crom este cel mai des întâlnit tip de tăbăcire din lume. Pieile tăbăcite în crom sunt caracterizate prin tuşeu de calitate înaltă, stabilitate hidro-termică ridicată şi proprietăţi excelente de utilizare. Deşeurile de crom de la prelucrarea pieilor reprezintă o problemă semnificativă de eliminare. Acestea apar în trei forme: deşeuri lichide, deşeuri tăbăcite solide şi nămol. În cele mai multe ţări, reglementările care guvernează eliminarea cromului din tăbăcării sunt stricte. Astăzi, toate tăbăcăriile trebuie să verifice cu atenţie fluxurile de deşeuri. Eliminarea cromului în aceste fluxuri reprezintă una dintre componentele care trebuie să fie strict controlate.

Impactul deşeurilor de crom din tăbăcării asupra mediului face subiectul unor dispute ştiinţifice şi tehnice extinse. S-au stabilit limite statutare pentru deversarea şi eliminarea cromului şi s-au elaborat linii directoare relevante în întreaga lume.

Având în vedere corelarea strânsă dintre tăbăcirea în crom şi impactul procesului de prelucrare a pieilor asupra mediului, auditarea eficienţei operaţiunilor de prelucrare capătă o mare importanţă.

Procesul convenţional de tăbăcire în crom implică, în general, piclarea, cromarea şi bazificarea, existând mai multe defecte în cadrul procesului $[1,2]$ : i) $8-10 \%$ sare şi $1,0-1,2 \%$ acid sulfuric se utilizează la piclare, ceea ce duce la conţinuturi mai mari de cloruri, sulfaţi şi consum chimic de oxigen (COD) în efluent; ii) absorbţia cromului în procesul convenţional de tăbăcire în crom este mai mică (70-80\%), o cantitate considerabilă de crom rămasă în efluent putând duce la probleme de mediu [3]; iii) se generează o cantitate mare de deşeuri solide cu conţinut de crom, cum ar fi şpalturi şi răzătură, care se degradează greu şi sunt dăunătoare mediului dacă sunt evacuate direct.

Utilizarea sărurilor de crom la tăbăcirea pielii a fost supusă multor critici, dar trebuie să se ţină cont de faptul că cromul poate exista în diferite stări de oxidare şi compuşii săi se comportă diferit. Majoritatea compuşilor de crom (VI) sunt extrem de toxici şi clasificaţi ca substanţe cancerigene MAK III A 2, dar cromul (III) este un oligoelement important pentru om şi animale. Cromul este menţionat în lista 2 din anexa la Directiva 76/464/CEE a Consiliului din 4 mai 1976 privind poluarea cauzată de anumite substanţe periculoase deversate în mediul acvatic al Comunităţii. 
Tannery wastes containing chromium are not included in the European Hazardous Waste List on the basis that the wastes do not possess the characteristics necessary for classification as a hazardous waste [4].

The Main Objective of the project was to develop a new "clean", eco-friendly tanning technology, alternative to chrome tanning (wet blue) and valorization of leather wastes obtained through this system. This new system includes obtaining new tanning agents (Knowledge-based Tanning Agents, KTA), a new tanning system, and obtaining a new type of leather, called "wet white".

The development of this innovative tanning system will significantly reduce the environmental impact (generating solid wastes and effluents without chromium), and people safety impact (leather without chromium). The solid wastes without chromium can be valorized as by-products with increased added value, leading to favourable economic and environmental benefits by increasing their life cycle (as compared to incineration which is currently practiced in EU, and disposal which is currently practiced in Romania).

S\&T objectives of the project were:

- synthesis of the new tanning agents (Knowledge-based Tanning Agents, KTA);

- development of new eco-technologies for leather pretanning/tanning;

- development of a new type of leather, called "wet-white";

- development of new conversion procedures of "wet-white" leather wastes into by-products with increased added value;

- transformation / functionalization of different peptides (obtained from "wet-white" leather wastes) by coupling/reticulating chemical reactions, into raw materials for obtaining new, biodegradable auxiliary materials destined for various applications: industrial, agriculture, cosmetics, etc.;

- development of new biodegradable auxiliary materials;

- LCA - Life Cycle Assessment Studies for the newly developed processes, as compared to the existing methods practiced today.
Deşeurile din tăbăcării care conţin crom nu sunt incluse în lista europeană a deşeurilor periculoase pe baza faptului că aceste deşeuri nu posedă caracteristicile necesare pentru clasificare ca deşeu periculos [4].

Obiectivul principal al proiectului constă în realizarea unor noi "tehnologii curate” prietenoase mediului şi omului, alternative tăbăcirii în crom (din care rezultă piei „,wet blue”) şi valorificării deşeurilor de piei obţinute prin acest sistem. Acest nou sistem include realizarea unor noi agenţi tananţi (Knowledgebased Tanning Agent, "KTA”), a unui nou sistem de tăbăcire şi obţinerea unui nou sortiment de piele, numit "wet white".

Realizarea acestui sistem inovator de tăbăcire va reduce semnificativ impactul asupra mediului (rezultând deşeuri şi efluenţi fără crom) şi asupra sănătăţii populaţiei (piei fără crom). Deşeurile fără crom pot fi valorificate ca subproduse cu valoare adăugată, obţinându-se efecte economice şi ecologice favorabile prin creşterea ciclului de viaţă (comparativ cu incinerarea care se practică în prezent în UE şi depozitarea în România).

Obiectivele tehnico-ştiinţifice ale proiectului au fost:

- sinteza unor noi agenţi de tăbăcire (Knowledge-based Tanning Agent, „KTA”);

- realizarea unor noi eco-tehnologii de pretăbăcire/tăbăcire a pieilor;

- realizarea unui nou sortiment de piele „wetwhite";

- elaborarea unor procedee de conversie a deşeurilor de piei wet-white în materii prime pentru produse cu valoare adăugată, cu utilizări în diverse domenii;

- transformarea/funcţionalizarea diferitelor peptide (obţinute din deşeuri de piei wetwhite) prin reacţii chimice de cuplare/ reticulare în: materii prime pentru obţinerea unor materiale auxiliare noi, biodegradabile pentru diferite aplicaţii industriale, în cosmetică, agricultură;

- realizarea noilor materiale auxiliare biodegradabile;

- studii LCA - Life Cycle Assessment (Evaluarea ciclului de viaţă) pentru noile procedee, comparându-se cu metodele actuale practicate în prezent. 
The scientific and technical objectives of the project initiate a new area of research in leather processing Knowledge-based Tanning Agent, which, correlated to the transformation/ functionalization of skin protein, contributes to the new concept of sustainable production by obtaining wet white leathers which do not use and do not generate chemicals which are toxic and prejudicial to humans and the environment.

\section{RESULTS AND DISCUSSION}

The main results obtained in the project were:

\section{KTA-M Tanning Agents Based on Ti and Al $[5,6]$}

Exploring the valorisation of solid titanium metallurgic end wastes, as a low cost raw material has yielded new tanning agents for the replacement of $\mathrm{Cr}$ (III) tanning salts to increase eco-efficiency in the leather manufacturing sector by making use of solid wastes, which cannot be recycled in the industry that generated them:

- total or partial replacement of chromium salts in the tanning process with cheap to produce and easy to apply in rapid full substance bovine leather manufacture, that, in turn required minimum process rationalisation or modification; moreover, the new mineral tanning agents are free of restricted or regulated metals: $\mathrm{Cr}, \mathrm{Pb}, \mathrm{Cd}, \mathrm{Hg}$ and $\mathrm{Ni}$;

- increase in articles diversity.
Obiectivele tehnico-ştiinţifice ale proiectului deschid un nou domeniu de cercetare în prelucrarea pieilor - Knowledge-based Tanning Agent care, corelat cu transformarea/funcţionalizarea proteinei pielii, contribuie la noul concept de producţie durabilă în care nu se folosesc şi nu rezultă produse chimice toxice şi vătămătoare pentru om şi pentru mediul înconjurător.

\section{REZULTATE ŞI DISCUTII}

Principalele rezultate obţinute în cadrul proiectului au fost:

\section{Agenţi tananţi KTA-M pe bază de Ti şi Al $[5,6]$}

Explorarea valorificării deşeurilor solide metalurgice de titan ca materie primă ieftină a dus la noi agenţi de tăbăcire pentru a înlocui sărurile tanante de $\mathrm{Cr}$ (III) în vederea creşterii eco-eficienţei în sectorul de fabricare a pielii utilizând deşeurile solide care nu pot fi reciclate în industria care le-a generat:

- înlocuirea totală sau parţială a sărurilor de crom în procesul de tăbăcire cu agenţi ieftini şi uşor de aplicat în fabricarea rapidă a pieilor de bovine, care necesită o minimă raţionalizare sau modificare a procesului; în plus, noii agenţi tananţi minerali nu conţin metale restricţionate sau reglementate cum ar $\mathrm{fi} \mathrm{Cr}$, $\mathrm{Pb}, \mathrm{Cd}, \mathrm{Hg}$ şi $\mathrm{Ni}$;

- creşterea diversităţii articolelor.
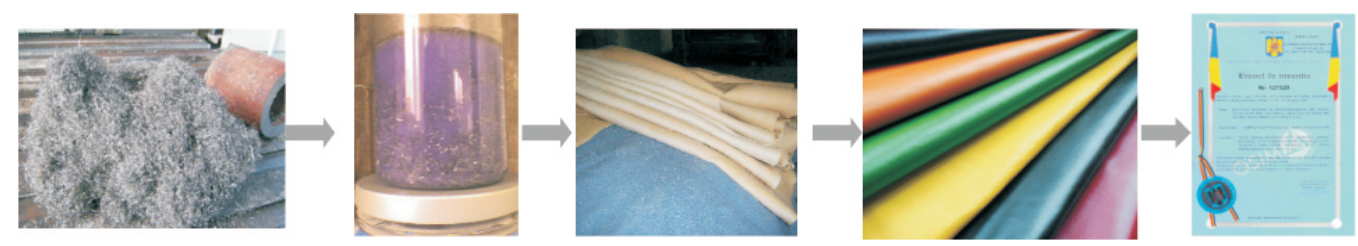

Figure 1. KTA-M tanning agents

Figura 1. Agenţi tananţi KTA-M

\section{KTA-S Tanning System Based on Resorcinol and Oxazolidine [7]}

Combinations of oxazolidines with resorcinol can replace chrome tanning without sacrificing the physical and thermal properties of the tanned leather. Finally,

\section{Sistem de tăbăcire KTA-S pe bază de rezorcină şi oxazolidină [7]}

Combinaţiile de oxazolidină cu rezorcină pot înlocui tăbăcirea în crom, fără a sacrifica proprietăţile fizice şi termice ale pielii tăbăcite. În cele din urmă, 
with the use of oxazolidine, a more effective salt-free pickling process can be achieved and the environmental impact within leather manufacturing can be further reduced. Since no chromium existed in the splittings and shavings, the wastes could be treated and reused more easily. utilizând oxazolidina se poate obţine un proces mai eficient de piclare fără sare şi impactul prelucrării pielii asupra mediului poate fi redus şi mai mult. Din moment ce şpalturile şi răzătura nu conţin crom, deşeurile pot fi tratate şi reutilizate mai uşor.
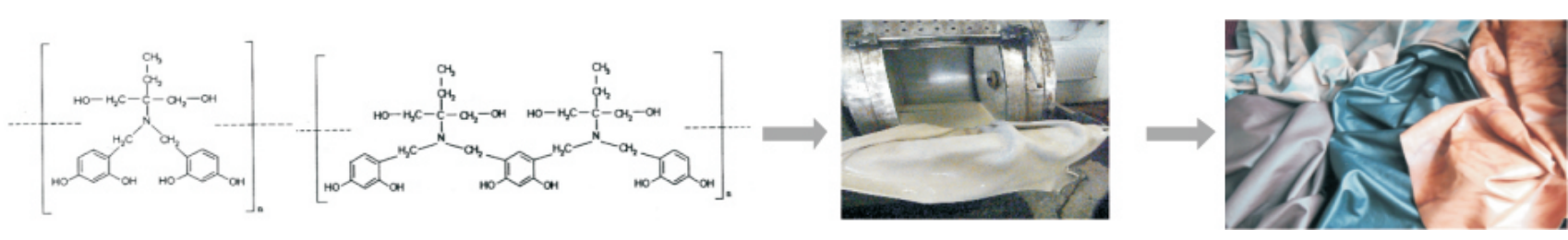

Figure 2. KTA-S tanning system

Figura 2. Sistem de tăbăcire KTA-S

\section{Obtaining New FOC (Free of Chrome) Leather Assortments: Bovine Upper Leather, Bovine Upholstery Leather, Clothing Leather $[8,9]$}

Free of chrome leather tanning system has many demonstrable advantages:

- no chromium in the effluents;

- solid leather wastes which can be recycled into value-added products (fertilizers and/or chemical auxiliaries used in leather industry and other industries, cosmetics);

- solid wastes (sludge resulted from purifying waste waters) without chromium;

- no risk of $\mathrm{Cr}(\mathrm{VI})$ - (causes cancer) formation from $\mathrm{Cr}(\mathrm{III})$;

- excellent shrinking behavior;

- brilliant dyeing, especially for fashion items;

- heavy metal free leathers for allergic persons;

- improved sorting leathers for various destinations, as early as the pretanning stage;

- the possibility of storage and marketing of wetwhite leathers;

- materials economy by sorting and assigning hides before tanning, to optimal sorts;

- reducing the depollution costs;

- more biodegradable leathers.
Obţinerea unor noi sortimente de piele fără crom (FOC - free of chrome): piele bovină pentru feţe încălţăminte, piele bovină pentru tapiţerie, piele pentru îmbrăcăminte $[8,9]$

Avantajele demonstrabile ale aplicării sistemului de tăbăcire a pieilor fără crom sunt:

- efluenţi fără crom;

- deşeuri solide de piele reciclabile în produse cu valoare adăugată (fertilizatori şi/sau auxiliari chimici cu utilizări în industria de pielărie sau alte industrii, cosmetică);

- deşeuri solide (nămol rezultat la epurarea apelor uzate fără crom);

- nu există risc de formare a $\mathrm{Cr}(\mathrm{VI})$ (care este cancerigen) din $\mathrm{Cr}(\mathrm{III})$;

- comportare foarte bună la contracţie;

- vopsiri strălucitoare, în special pentru modă;

- piei fără conţinut de metale grele pentru persoanele alergice;

- îmbunătăţirea sortării pieilor pentru diverse destinaţii, încă din faza de pretăbăcire;

- posibilitatea de stocare şi comercializare a pieilor sub formă wet-white;

- economie de materiale prin sortarea şi orientarea pieilor înainte de tăbăcire, spre sortimente optime;

- reducerea costurilor de depoluare;

- piei mai biodegradabile. 


\section{Valorization of Wet-White Leather Waste}

The Concept of Conversion / Functionalization of Skin Protein (Collagen)

It is known that improving the performance of a synthetic polymer is possible by applying the generic strategy called "chemical modification". The objective is targeted mainly towards functionalization of the macromolecular compound, so that it can be used to obtain customized composite materials, either by a thermodynamic compatibility or a special intercoupled, full IPN or semi-IPN configuration. Novelty of solutions proposed in the project consists in extending the concepts of "chemical modification" to the natural polymer, collagen, both by polymeranalogous transformations, as well as reactions of grafting.

Studies have been made for transferring the solid wet-white leather waste into raw materials which can be used for development of novel bio-composites (fertilizers and/or chemical auxiliaries used in leather industry and other industries, cosmetics) (Figures 3, 4, $5)$.

\section{Valorificarea deşeurilor de piele wet-white}

Conceptul de conversie/funcţionalizare a proteinei din piele (colagen)

Se cunoaşte faptul că îmbunătăţirea performanţelor unui polimer sintetic este posibilă prin aplicarea strategiei denumită generic „modificare chimică". Obiectivul acesteia este orientat, în principal, spre funcţionalizarea compusului macromolecular, astfel încât acesta să poată fi utilizat la obţinerea de materiale compozite particularizate, fie prin compatibilitate de tip termodinamic, fie cu o configuraţie specială de tip intercuplat, full IPN sau semi-IPN. Noutatea soluţiilor propuse în cadrul proiectului constă în extinderea acestor concepte de „modificare chimică” la polimerul natural, colagen, atât prin transformări polimeranaloage, cât şi prin reacţii de grefare.

S-au efectuat studii pentru transferul deşeurilor solide de piele wet-white în materii prime care pot fi folosite pentru dezvoltarea unor noi bio-compozite (îngrăşăminte şi/sau auxiliari chimici utilizaţi în industria de pielărie şi alte industrii, produse cosmetice) (Figurile 3, 4, 5).

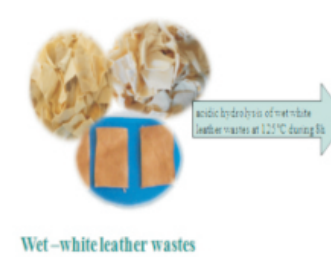

Wet-white leather wastes

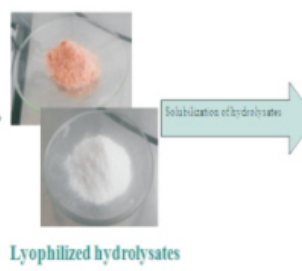

Lyophilized hydrolysates

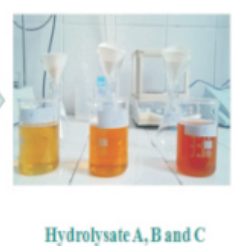

Hvdrolysate A, B and C
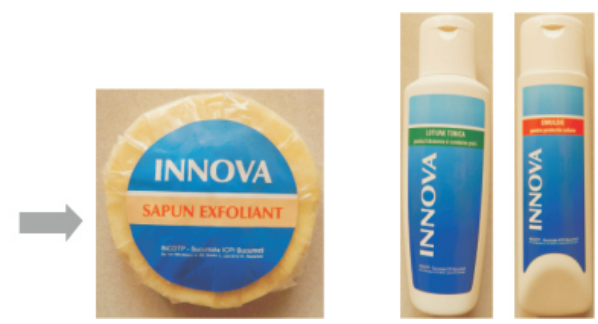

Figure 3. Obtaining of new cosmetics [10]

Figura 3. Obţinerea unor noi produse cosmetice [10]
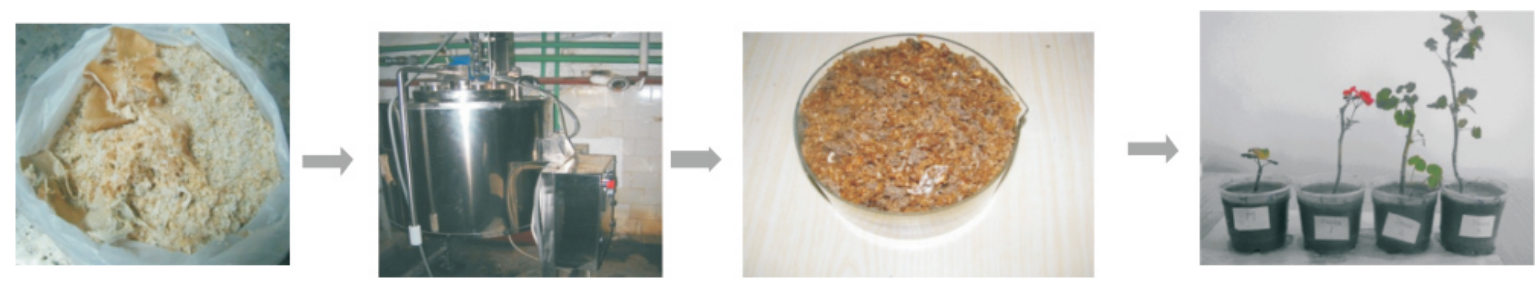

Figure 4. Obtaining the soil remediation product for agriculture [11, 12]

Figura 4. Obţinerea unui produs pentru remedierea solurilor cu aplicare în agricultură $[11,12]$ 

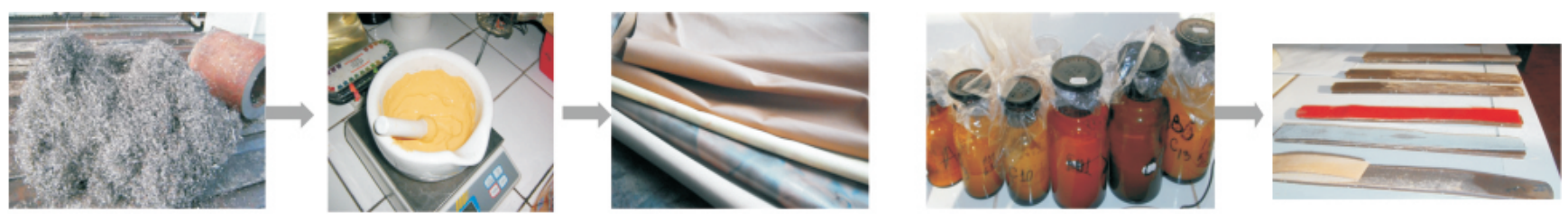

Figure 5. Obtaining pigment paste for leather finishing and adhesive for footwear sector [13]

Figura 5. Obţinerea unei paste de pigment pentru finisarea pieilor

şi a unui adeziv pentru sectorul de încălţăminte [13]

\section{Life Cycle Assessment Comparative Study for the Two Tanning Systems}

Application of new tanning systems and transformation of the solid leather waste into new value-added products lead to remarkable life-cycleimprovements of the starting materials and close loops in terms of sustainable utilization of former wastes, increasing the eco-efficiency and economic efficiency of leather sector. LCA comparative study between chrome tanning $(\mathrm{Cr})$ and tanning leather with KTA-M system (FOC) revealed the results presented in Figures 6,7 and 8 .

\section{Studiul de evaluare a ciclului de viaţă pentru cele două sisteme de tăbăcire}

Aplicarea noilor sisteme de tăbăcire şi de transformare a deşeurilor solide de piele în noi produse cu valoare adăugată duce la îmbunătăţiri remarcabile ale ciclului de viaţă al materiilor prime şi la circuite închise în ceea ce priveşte utilizarea durabilă a deşeurilor, creşterea eco-eficienţei şi a eficienţei economice în sectorul de pielărie. Studiul comparativ LCA între tăbăcirea în crom $(\mathrm{Cr})$ şi tăbăcirea pieilor cu sistemul KTA-M (FOC) a dus la rezultatele prezentate în Figurile 6, 7 şi 8.

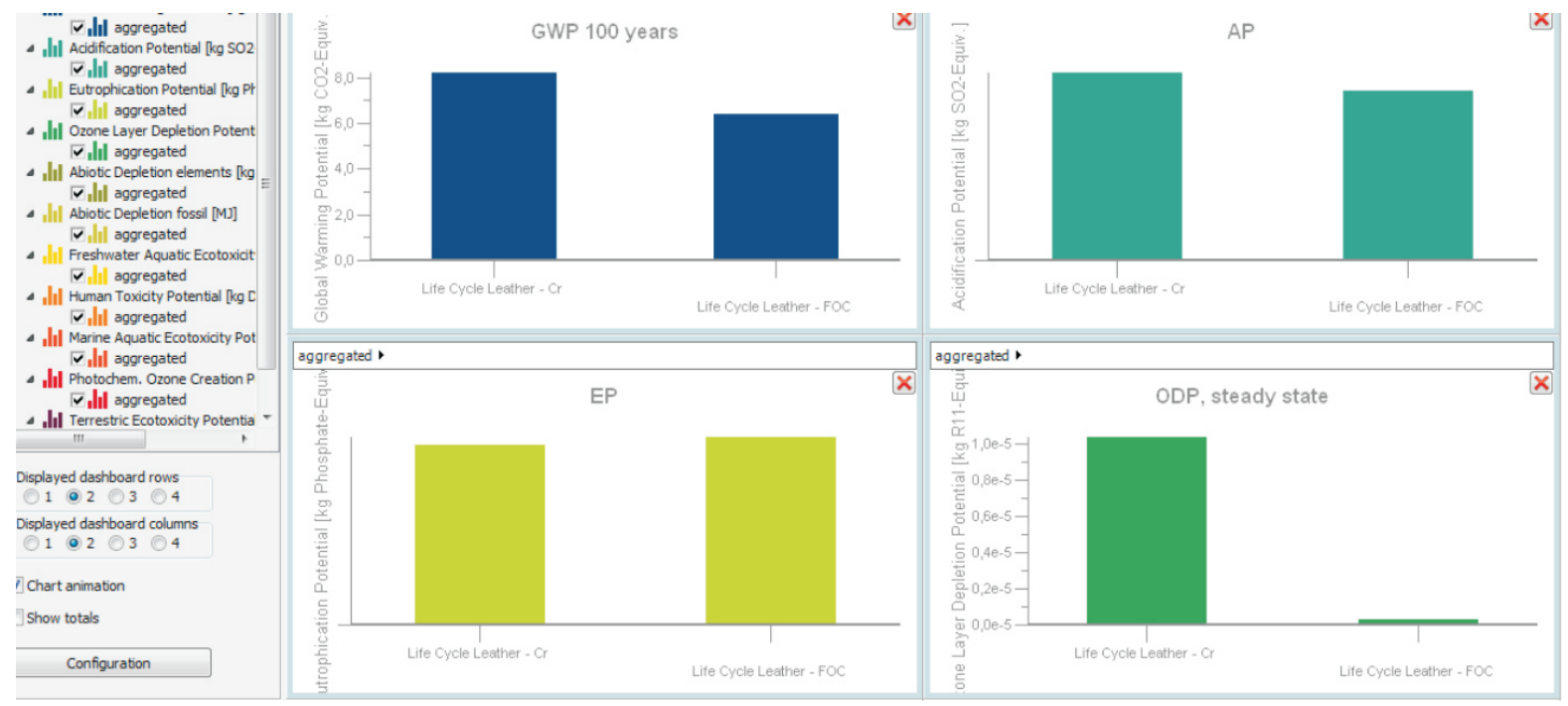

Figure 6. Global Warming Potential (GWP), Acidification Potential (AP), Eutrophication Potential (EP) and Ozone Depletion Potential (ODP)

Figura 6. Potenţialul de încălzire globală (GWP), Potenţialul de acidifiere (AP), Potenţialul de eutrofizare (EP) şi Potenţialul de diminuare a ozonului (ODP) 


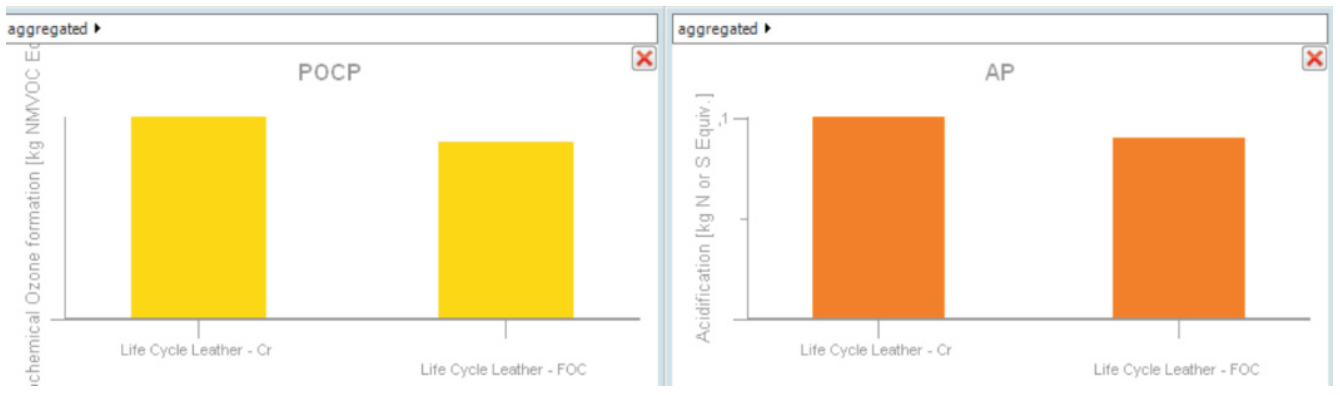

Figure 7. Photochemical Ozone Creation Potential (POCP), Acidification Potential (AP)

Figura 7. Potenţialul de formare a ozonului fotochimic (POCP), Potenţialul de acidifiere (AP)

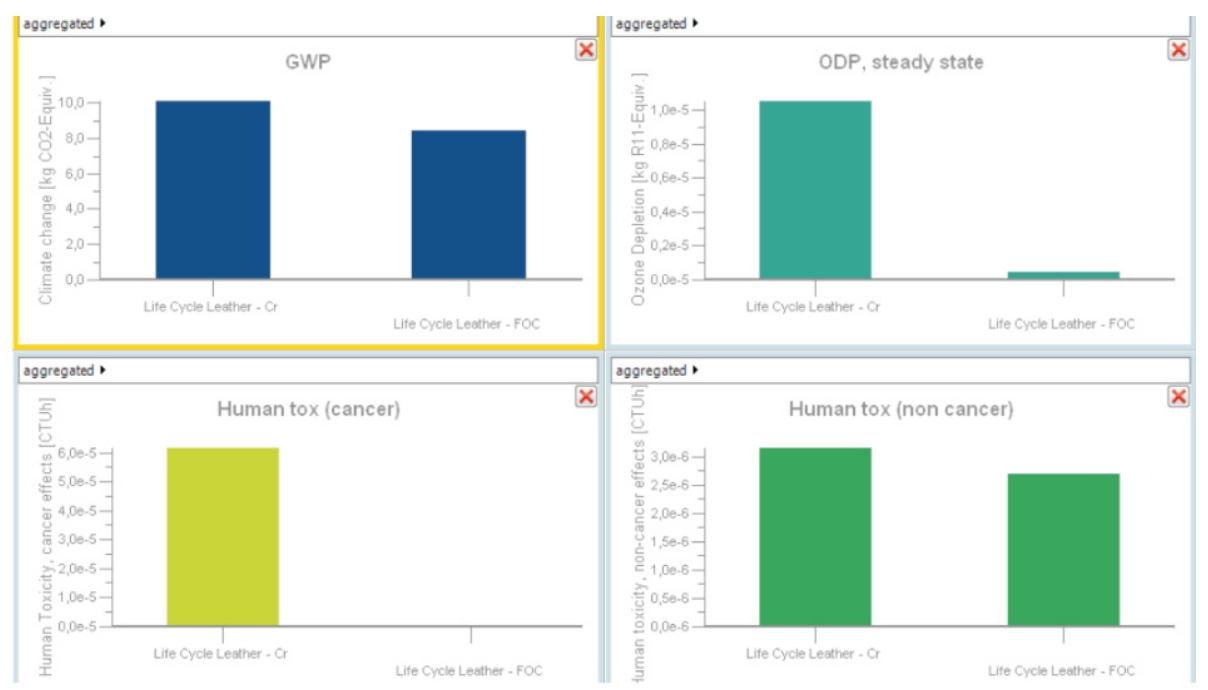

Figure 8. Impact indicators for both systems: carbon footprint (GWP), Ozone Depletion Potential (ODP), human toxicity

Figura 8. Indicatori de impact pentru ambele sisteme: amprenta de carbon (GWP), Potenţialul de diminuare a ozonului (ODP), toxicitate umană

The carbon footprint obtained for KTA-M-Ti-Al technology system was $9.7250 \mathrm{~kg} \mathrm{CO}$, equiv. and for chrome tanning system was $11.4848 \mathrm{~kg} \mathrm{CO}_{2}$ equiv.

The main conclusion of the study is that the new KTA-M overall tanning technology developed in INNOVA-LEATHER project generates a $15 \%$ lower environmental impact measured as carbon footprint (Global Warming Potential indicator) than the classic chrome tanning technology. The other calculated impact category indicators have comparable values between the two technologies.

\section{New Data Bases}

Five new data bases were developed regarding: DB1 - Environmental legislation database for the
Amprenta de carbon obţinută pentru sistemul de tehnologie KTA-M-Ti-Al a fost de 9,7250 kg echiv. de $\mathrm{CO}_{2}$ şi pentru sistemul de tăbăcire în crom a fost de 11,4848 kg echiv. de $\mathrm{CO}_{2}$.

Principala concluzie a studiului este că noua tehnologie de tăbăcire KTA-M dezvoltată în cadrul proiectului INNOVA-LEATHER generează un impact asupra mediului cu $15 \%$ mai mic măsurat ca amprenta de carbon (indicator al potenţialului de încălzire globală), decât tehnologia clasică de tăbăcire în crom. Ceilalţi indicatori calculaţi ai categoriilor de impact au valori comparabile pentru cele două tehnologii.

\section{Noi baze de date}

Au fost elaborate cinci baze de date noi cu privire la: DB1 - Baza de date a legislaţiei de mediu pentru 
leather and footwear industry [14], DB2 - Clean technologies for leather manufacture, DB3- Specific analysis for leather, DB4 - Information about Romanian companies from leather-footwear sector and DB5 Project results $[15,16]$. industria de pielărie şi încălţăminte [14], DB2 Tehnologii curate pentru fabricarea pielii, DB3 - Analize specifice pentru piele, DB4 - Informaţii despre firme româneşti din sectorul de pielărie-încălţăminte şi DB5 Rezultatele proiectului $[15,16]$.
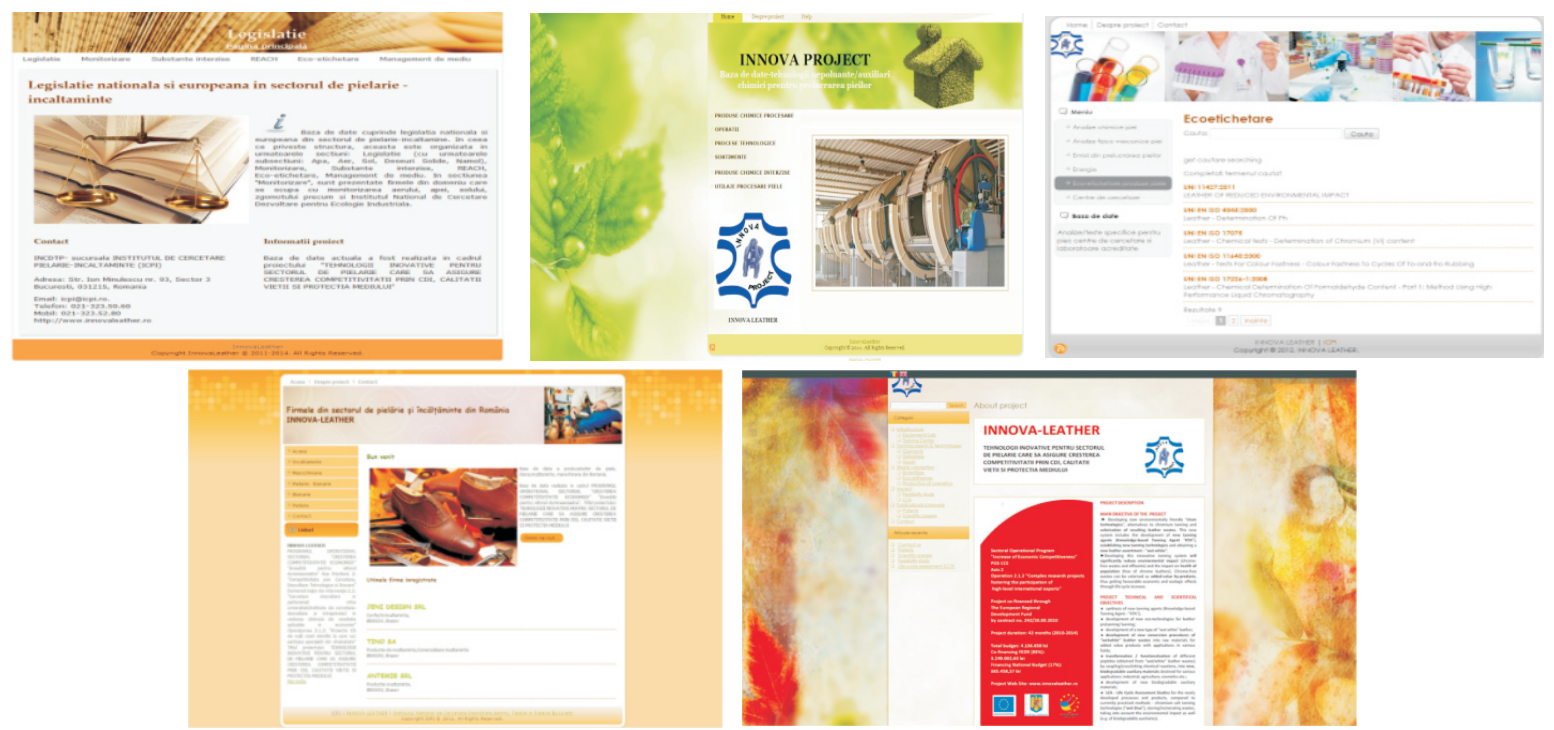

Figure 9. Data bases developed in the project

Figura 9. Bazele de date dezvoltate în cadrul proiectului

\section{Patents and Awards}

The innovative solutions made the object of 5 patent applications and were awarded with 7 Gold medals and 3 special awards at important international fairs.

\section{Brevete şi premii}

Soluţiile inovatoare au făcut subiectul a 5 cereri de brevet şi au fost premiate cu 7 medalii de aur şi 3 premii speciale la târguri internaţionale importante.
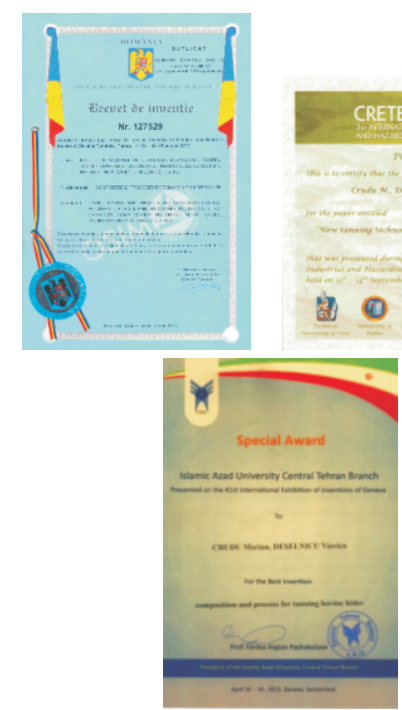
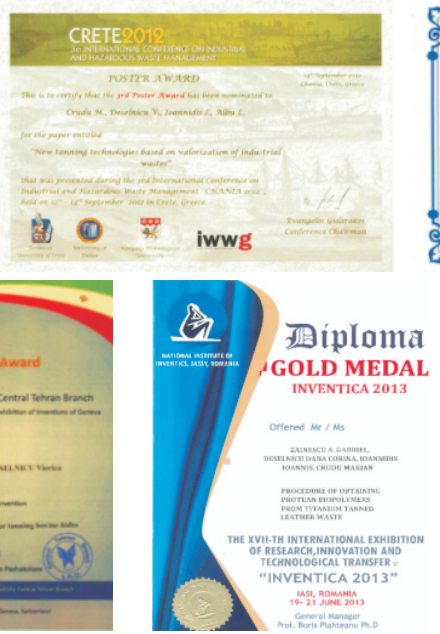
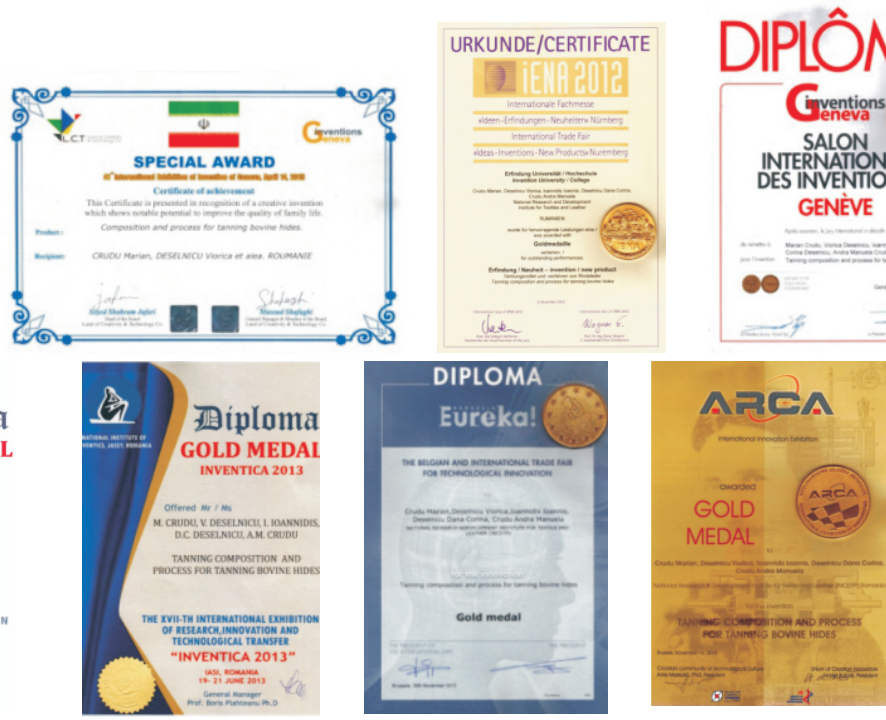

Figure 10. Patents and awards received

Figura 10. Brevete şi medalii obţinute 


\section{Beneficiaries}

The main beneficiaries of the project results are:

\section{Direct Beneficiaries}

1) INCDTP - Division ICPI by:

- The implementation of the project created a scientific and technologic competence core by research - development - innovation within INCDTP Division ICPI in the leather processing field at European standards, having as a result the development of new products, technologies and services, with high added value and market demand, as a basis for technological transfer in the industrial sector and production application.

2) Civil society by living in a less pollutant environment for a healthy life.

3) The leather industry in Romania (tanneries), mostly SMEs;

4) The Association of Leather and Fur Manufacturers in Romania and The Owners Organization in the Leather Footwear Industry, which are interested in the project realization and are directly capitalizing its results, thus contributing to the project implementation process.

\section{Indirect Beneficiaries}

1) Related industries: footwear, leather clothing confections, morocco goods, fashion.

2) The chemical industry in Romania/Europe, because, in the project, methods of sustainable use of wet white leather wastes were elaborated, supporting thus the use of renewable resources other than oil.

3) Food industry (butcheries) from which result significant quantities of inedible wastes, which can be recovered by similar procedures, after adaptation (the elaboration of a new project is taken into account for recovering these wastes).

4) Cosmetics - by making new products with animal protein content

5) Agricultural sector by applying the fertilizers obtained from wastes.

6) Education system - pupils, students, teaching staff, benefiting from the new information acquired by elaborating the project.

\section{Beneficiari}

Principalii beneficiari ai proiectului sunt:

\section{Beneficiari direcţi}

1) INCDTP Sucursala ICPI prin:

- Realizarea proiectului conduce la crearea unui nucleu de competenţă ştiinţifică şi tehnologică prin cercetare - dezvoltare - inovare în cadrul INCDTP Sucursala ICPI în domeniul prelucrării pieilor la standarde europene, având ca rezultat dezvoltarea de produse, tehnologii şi servicii noi, perfecţionate, cu valoare mare adăugată şi cu cerere de piaţă, ca bază pentru realizarea transferului tehnologic în sectorul industrial şi aplicarea în producţie;

2) Societatea civilă prin convieţuirea într-un mediu înconjurător mai puţin poluant pentru o viaţă mai sănătoasă;

3) Industria de pielărie din România (tăbăcăriile), care, în majoritate sunt IMM-uri;

4) Asociaţia Producătorilor de Piele şi Blană din România şi Organizaţia Patronală din industria de Pielărie Încălţăminte care sunt interesate de realizarea proiectului şi capitalizează direct rezultatele acestuia, contribuind astfel la procesul de implementare al proiectului.

\section{Beneficiari indirecţi}

1) Industrii conexe: încălţăminte, confecţii îmbrăcăminte din piele, marochinărie, modă;

2) Industria chimică din România/Europa, deoarece în proiect vor fi elaborate metode de utilizare durabilă a deşeurilor de piei wet white, fiind astfel susţinută folosirea resurselor reînnoibile, altele decât cele petroliere;

3) Industria alimentară (abatoare) unde rezultă, de asemenea, cantităţi importante de deşeuri necomestibile, ce pot fi valorificate prin procedee similare, după adaptare (se are în vedere realizarea unui alt proiect pentru valorificarea acestor deşeuri);

4) Cosmetică - prin realizarea unor produse noi cu conţinut de proteină animală;

5) Sectorul agricol prin aplicarea fertilizatorilor obţinuţi din deşeuri;

6) Sistemul de educaţie - elevi, studenţi, cadre didactice care vor beneficia de noile cunoştinţe dobândite prin realizarea proiectului. 


\section{CONCLUSIONS}

Application of new innovative tanning systems significantly reduces the environmental impact (generating solid wastes and effluents without chromium), and people safety impact (leather without chromium). The solid wastes without chromium can be valorized as by-products with increased added value, leading to favourable economic and environmental benefits by increasing their life cycle (as compared to incineration which is currently practiced in EU, and disposal which is currently practiced in Romania).

The Project's results contribute to the development and validation of a sustainable production system for the leather sector in Romania.

\section{Acknowledgements}

This work was supported by the European Fund for Regional Development and the Romanian Government in the framework of Sectoral Operational Programme under the project INNOVA-LEATHER: «Innovative technologies for leather sector increasing technological competitiveness by RDI, quality of life and environmental protection» - contract POS CCE-AXIS 2-O 2.1.2 no. 242/20.09.2010 ID 638 COD SMIS-CSNR 12579.

\section{CONCLUZII}

Prin aplicarea noului sistem inovator de tăbăcire se va reduce semnificativ impactul asupra mediului (rezultând deşeuri şi efluenţi fără crom) şi asupra sănătăţii populaţiei (piei fără crom). Deşeurile fără crom pot fi valorificate ca subproduse cu valoare adăugată, obţinându-se efecte economice şi ecologice favorabile prin creşterea ciclului de viaţă (comparativ cu incinerarea care se practică în prezent în UE şi depozitarea în România).

Rezultatele proiectului contribuie la dezvoltarea şi validarea unui sistem durabil de producţie în sectorul de pielărie din România.

Mulţumiri

Această lucrare a fost finanţată de Fondul European pentru Dezvoltare Regională şi Guvernul român, în cadrul Programului Operaţional Sectorial, în cadrul proiectului INNOVA LEATHER: «Tehnologii inovative pentru sectorul de pielărie care să asigure creşterea competitivităţii prin CDI, calităţii vieţii şi protecţia mediului» - contract POS CCE-AXA 2-O 2.1.2 nr. 242/20.09.2010 ID 638 COD SMIS - CSNR 12579.

\section{REFERENCES}

1. Germann, H.P., J Soc Leather Tech Chem, 1995, 79, 3, 82-85.

2. Sykes, R.L., Coning, S.B., Earl, N.J., J Am Leather Chem Assoc, 1981, 76, 3, 102-125.

3. Ludvik, J., UNIDO Report US/RAS/92/120, 1997, 15.

4. COTANCE, The European Tanning Industry Sustainability Review, 2002, World Summit on Sustainable Development.

5. Crudu, M., Deselnicu, V., Deselnicu, D.C., Albu, F.L., Valorization of titanium metal wastes as tanning agent used in leather industry, Waste Manage, 2014, 34, 1806-1814, DOI information: 10.1016/j.wasman.2013.12.015.

6. Crudu, M., Deselnicu, V., loannidis, I., Crudu, A., New wet white tanning Agents and Technology, Proceedings of The 4th ICAMS 2012, 27-34, 27-29 September 2012, Bucharest, RO.

7. Deselnicu, V., Crudu, M., loannidis, I., Deselnicu, D.C., Synthetic organic tanning system, Proceedings of The 4th ICAMS 2012, 41-48, 27-29 September 2012, Bucharest, RO.

8. Chirila, C., Crudu, M., Deselnicu, V., Study regarding the resistance to the growth of fungi of wet-white leather tanned with Titanium - Aluminum, Revista de Pielarie Incaltaminte (Leather and Footwear Journal), 2014, 14, 2, 19-26.

9. Ioannidis, I., Biodegradable materials - Some untold tales of fiction and consumer high expectations, Revista de Pielarie Incaltaminte (Leather and Footwear Journal), 2011, 11, 1, 33-42.

10. Albu, M.G., Ioannidis, I., Ghica, M.V., Deselnicu, V., Chelaru, C., Coara, Gh., Proteic Ingredients for cosmetic product, Proceedings of The 4th ICAMS 2012, 21-26, 27-29 September 2012, Bucharest, RO.

11. Zainescu, G., Deselnicu, D.C., Ioannidis, I., Crudu, M., Voicu, P., New versatile conversion technology for wet white 
waste transformation into biofertilisers, Proceedings of The 4th ICAMS 2012, 71-76, 27-29 September 2012, Bucharest, RO.

12. Zainescu, G., Albu, L., Deselnicu, D.C., Constantinescu, R., Vasilescu, A.M., Nichita, P., Sarbu, C., A new concept of complex valorization of leather wastes, Materiale plastice, 2014, 51, 1, 90.

13. Deselnicu, D.C., Militaru, Gh., Deselnicu, V., Obtaining of biodegradable plastic materials, Materiale plastice, 2014, $51,1,72$.

14. Macovescu, G., Guta, A.S., Environmental legislation database for the leather and footwear industry, Revista de Pielarie Incaltaminte (Leather and Footwear Journal), 2012, 12, 1, 19-26.

15. Guta, S.A., Bostaca, Gh., Macovescu, G., INNOVA LEATHER: A knowledge based platform for sustainable leather manufacture, Proceedings of The 4th ICAMS 2012, 49-54, 27-29 September 2012, Bucharest, RO.

16. Hanchevici, A.B., Guta, A.S., Supervised multi-agent control of leather manufacturing processes by using the fuzzy logic, Revista de Pielarie Incaltaminte (Leather and Footwear Journal), 2012, 12, 2, 101-113. 